\title{
The Enchanted Storyteller: John Barth and the Magic of Scheherazade
}

\author{
Maryam Moosavi Majd ${ }^{a}$, Nooshin Elahipanah ${ }^{\mathrm{b}}$ \\ Foreign Languages Faculty, Semnan University, Iran \\ E-mail address: ${ }^{*}$ Maryam.moosavi.majd@gmail.com, ${ }^{b}$ nelahipanah@semnan.ac.ir
}

\section{Keywords: John Barth, Scheherazade, Narrative, Frame tale, Embedding}

\begin{abstract}
During the fifties he was considered to be an existentialist, and absurdist and later a Black Humorist, yet, John Barth proved that he would never subscribe to any specific theory and would make his own world of/about fiction by himself. A traditional postmodernist as some of the critics calls him; he was obsessed with Scheherazade the narrator of the Thousand and one Nights and her art of storytelling. This essay aims to depict Barth's employment of the frame narrative and embedding structure which are the main devices of Scheherazade's mystifying narratives. Revealing the architectonic structure of his writing, we would demonstrate how traditional technique can bridge postmodernist aesthetics to recreate and replenish the exhausted materials in writings.
\end{abstract}

\section{INTRODUCTION}

As an academic writer, John Barth started his career early 1960s, his first few novels The SotWeed Factor (1960) Giles Goat-Boy(1966) demonstrate his tendency toward eighteenth century novelists like Fielding, Smollett and Stern, instead of his modernist predecessors. He even chose his mentors from the earlier writers like Boccaccio and Cervantes. However Barth attempted to transcend his ancestors by recreating his own world with the help of mythical proportions and frame tale convention. The frame tale strategy appeals to him since it answers his anti-realistic vocations. As a storyteller, Barth prefers to create his own fictional world rather than imitating the real one. Therefore through frame tale device he maintains to fulfill his desire for they refer to series of interconnected tales rather than direct experience of life. Barth exploits the convention which is as old as Homer's epic, to generate his self-conscious, self-reflexive collection of short stories, Lost in the Funhouse(1968). Emulating the oral tradition, Barth subtitled the series as Fiction for Print, Tape, Live Voice that echoes his fascination to oral storytelling, moreover he employed the frame structure in the form of a Mobius Strip, which put the story in a loop with no sense of beginning and endingan infinite regress. He developed the technique in Chimera(1972) as he managed to intrude his text as an author who descends in the world of Scheherazade and her eternal realm of storytelling.

In Chimera Barth illustrates his passion for the past by applying his aesthetics for writing. The book contains three loosely connected stories which are hinged on a grand history and myths. Since Barth's logic for replenishment takes place by recycling the past, which is not a mere repetition but rewriting and reenactment, Chimera's formal aspect must first be considered as Barth's creative approach toward replenishment. Framing its three parts in the mythological past, he managed to rewrite the myths in order to unmask the ideology behind them. The author acts as if he is one of the characters in the text. Thus the fictional characters are framed by the author as much as he is framed by them. Their interdependence is explicitly shown in Barth's famous statement that "If Sinbad sinks, its Scheherazade who drowns; whose neck one wonders is on her line?" (Lost in the Funhouse 121) Chimera is considered to be the author's life story framed in the frame narrative of the Thousand and One Nights, which makes it a küntlerroman (Ziegler 62) where the author meet his muse, Scheherazade; as if by magic. Barth exploited the convention of frame tales in Chimera, to increase the complexity and express his own innovation in postmodern aesthetics. However in his later novels like, LETTERS (1979), Sabbatical: A Romance (1982) or the Tidewater Tales (1987), he no longer wishes to novelize this convention. Yet Barth, who can never escape Scheherazade's 
spell, revisits the frame tale of the Thousand and One Nights, and Scheherazade's stories of the "Seven Voyages of Sindbad the Sailor" in The Last Voyage of Somebody the Sailor (1991) This novel seems to be the dénouement of Barth's obsession with Scheherazade, since in this fat novel, Barth deals with an apocalyptic ending of storytelling through series of frame tales. Both his protagonist and Scheherazade are dealing with Death and therefore must create a virgin story out of the exhausted material.

\section{JOHN BARTH'S POSTMODERNISM}

Charles B. Harris described John Barth's writing as the emanation of "passionate virtuosity: algebra and fire" where "algebra", the form and technique, is successfully combined with "fire", the "unique and original expression." (Harris 6) Max F. Schulz explains Barth's method as an aesthetic one in which he explores traditional literature specifically realism: "His fiction is the outgrowth of this "impulse to go back to the beginning of things, to see to what contemporary uses they might be put [and that $t$ ]he literary preoccupation of his lifetime has been the metafictional concerns of selfreflexivity and intertextuality. (M. Schulz xii)

Barth's approach on postmodernism and metafictional writings are mostly expressed in his two famous essays two essays "The Literature of Exhaustion "and "The Literature of Replenishment". There he initially described the deficiency of the realistic literature, particularly their narrative techniques, to highlight that they are no longer sufficient for narrating the contemporary writings.

Whereas Modernist texts obliged the reader to reclaim a consistent logic of the structure, chronological order or even the character's motivation etc, by their own ingenuity ; the ludic postmodernist uses metafictional techniques to motivate the reader for discovering the what is in the text and what is beyond it. According to Patricia Waugh:

Metafiction is a term given to fictional writing which self-consciously and systematically draws attention to its status as an artefact in order to pose questions about the relationship between fiction and reality. In providing a critique of their own methods of construction, such writings not only examine the fundamental structures of narrative fiction, they also explore the possible fictionality of the world outside the literary fictional text.(2)

Metafiction preserve familiarity and innovation simultaneously since the reader can balance the massages better if he/she recognizes a familiar form in the text. In this respect Waugh suggested that the forms and language of the experimental text should not be "so unfamiliar" because it risks the danger of being "rejected as simply not worth the reading effort"(64)

In order to explain the familiarity in Barth's metafictional writings deployed by the use of frame tale convention and embedded stories, one has to run a meticulous survey on the narrative level to dismantle the complex structure that leave the reader/audience suspended but at the same time interested in the narrative.

\section{DISCUSSION}

Gérard Genette, introduced the narrative level for the first time in his The Narrative Discourse: An Essay in Method. To Genette a narrating situation, like any other "complex whole" needs to be analyzed in details. Thus he categorized its most important components as "time of the narrating, narrative level, and "person"'". (italic in the original Genette 215) Narrative levels are usually recognized to be associated with narrative farming and embedding. Although the two strategies are intricately intertwined yet it is necessary to remember that they cover different domains. Prince in his Dictionary of Narratology regarded embedding as one of the methods in which narrative sequences can be linked within a narrative instance and in this respect it is a device 
associated with story. (Pier 3) In order to understand the process of embedding in the narrative situation I benefited from M. M. Bakhtin's theory about the dialogic nature of language and draw the similarities that establish the narrative as a smaller portion of the language system.

\section{Bakhtin's Theory of Heteroglossia}

M.M. Bakhtin the modern literary theorist who is considered to be the most original thinker of the twentieth century, introduced the concept the dialogic to the critical theory.(My italic) According to Bakhtin, "all language is a dialogue in which a speaker and a listener form a relationship."(Bressler 45) Subsequently he exercised the term heteroglossia, to indicate the diversity of languages.

Language is not a neutral medium that passes freely and easily into the private property of the speaker's intentions; it is populated-overpopulated-with the intentions of others. Expropriating it, forcing it to submit to one's own intentions and accents, is a difficult and complicated process...it exists in other people's mouths, in other people's contexts, serving other people's intentions : it is from there that one must take the word, and make it one's own. (Bakhtin 295)

Bakhtin explored the notion of heteroglossia in his essay "Discourse in the Novel" from Dialogic Imagination. There he defines the novel as a "diversity of social speech types sometimes even diversity of languages and a diversity of individual voices, artistically organized"(262) $\mathrm{He}$ emphasized that this stratification of the language and social heteroglossia is indispensible for an authentic prose.(264) In this respect

The novel orchestrates all its themes, the totality of the world of objects and ideas depicted and expressed in it, by means of the social diversity of speech types [raznorečie] and by the differing individual voices that flourish under such conditions. Authorial speech, the speeches of narrators, inserted genres, the speech of characters are merely those fundamental compositional unities with whose help heteroglossia [raznorečie] can enter the novel; each of them permits a multiplicity of social voices and a wide variety of their links and interrelationships (always more or less dialogized). (263)

Bakhtin believes that the novel is the youngest genre among the major genres and it is also the most "novelized".(3-5) It is also a genre that withhold any kind of stylization, among them, "Parodic stylizations of canonized genres and styles occupy an essential place in the novel."(6) Bakhtin considers that the novel parodies the other genres and squeezes them into its own structure and finally reformulates and reaccentuates them.(5) Temporally speaking, the novel came to contact the present significantly, however it constantly push the limits and plunge into the past by the use of parody. On the other hand it crosses the boundaries by pulling the future into the text. He suggested that this inconclusiveness of the present is the only reason that "keeps the genre from congealing"(27)

Despite the fact that Bakhtin does not directly use the word embedding, his dialogic heteroglossia the existence of multiple languages in the novel ;is reminiscent of the existence of multiple temporal locations as past, present and the future. He assumes that:

$[T]$ he entire novel breaks down into images of languages that are connected to one another and with the author via their own characteristic dialogical relationships. [...] The author participates in the novel [...] with almost no direct language of his own. The language of the novel is a system of languages that mutually and ideologically interanimate each other. (47)

Bakhtin indicates that the dialogical languages in the novel are not just languages but "images of languages" which flow through the author into the text. The existence of multiple stories embedded to each other is there for can be regarded as images or textual representation of these languages. 
These stories accordingly have mutual relation and interrelation that consequently make up the novels dialogic conversation.

\section{EMBEDDING STRUCTURE}

According to Oxford Dictionary ${ }^{1}$ the verb "embed" technically means to "place (a phrase or clause) within another clause or sentence". Thus the embedding narrative is refers to a narrative that includes embeded narratives. In case of embedding, tales are involved in a way that at some point they are linked together. This shared point remind us of Bakhtin's shared system of languages where the languages converse to each other according to some key phrase or words etc. . Similarly in embedding the stories can indirectly be recognized by the reader through shared themes or plot or symbols, etc.

The most classic example of embedded narrative is the stories in the One Thousand and One Nights. There the primary narrative reveals the story of Scheherazade whose life is threatened by King Shahryar. The only way she could escape is to amuse the king with marvelous stories every night. So she tells a story within which a new story is embedded and this will continue for a thousand and one nights. Scheherazade tells story A in which a character tells story B where another person tells story C, etc. Sometimes these stories are embedded within, until the eights level.

Meik Bal discussed embedded texts and narratives in his Narratology: Introduction to the Theory of Narrative. According to Bal one of the characteristics of embedded text is that he primary narrative is gradually forgotten after some times by the reader or listener. (53)Bal described the Nights as a good representative of this situation. He pointed that this forgetting is quite necessary in Scheherazade's survival.(53) As readers forget the primary narrative;

[T]his forgetting is a sign that Scheherazade's goal has been accomplished. As long as we forget that her life is at stake, the king will too, and that was her purpose. In that case, the apparently loose relationship between primary and embedded text is relevant to the development of the primary fabula.(53)

Bal continues to clarify the relationship between the primary story and the embedded ones. Accordingly there are two possibilities, either the embedded story explain the primary story or resemble it. (53) In case of the first proposal, the relationship is made explicit by the narrator of the embedded story, however in the second condition although there would be some hints; the task is left to the audience.(54) However despite the fact that the embedded stories shared system and their role in plot and narration, they can function independently as a particular story. Furthermore the embedded narration promotes multiple reading from the text and gives the chance to various interpretations. In other words, the coding system in embedded stories permits them to be combined with the real life contexts and situations familiar to the reader.

The practice of embedding stories returns to the very time that the oral storytelling was popular in epics and it is still continued to be practiced in the ludic postmodern texts. Looking back to many works that applied this technique, one would ask about the reason of the popularity of this technique for such a long time. David Herman suggested that the attraction toward this mechanism of inserting one story into another is primarily cognitive and functions as vehicles of "shared thinking, or socially distributed cognition."(3) Narrative embedding, like any other rational activity, requires a functional system. The embedded stories are usually established within frames which are normally understood as a kind of enclosing. In framed narratives, which are the simulation of oral storytelling; stories get embedded within other stories to where the narrator of each frame, narrate another story within which its character/characters, tell another story, etc. Thus we reach to what

\footnotetext{
1 "Embed" Oxford Online Dictionary

$<$ http://www.oxforddictionaries.com/definition/english/embed $>$
} 
Todorov declared in his Poetics of Prose, that "embedding narrative is the narrative of a narrative" (Todorov 71).

\section{FRAMING DEVICE}

Framing technique is an old literary device found even in the oral narrations. A framed narrative is referred to a set of embedded stories enclosed within a larger framework. Narrative frame usually invoke an oral environment in the text since it explicitly emphasize on the relationship between a storyteller and the audience. According to Peter Brook in Reading for the Plot: Design and Intention in Narrative; framed narrative dramatize the relation between "tellers and listeners, narrators and narrates [...] looking for the sign of recognition and the promise to carry on".(28) Recalling Bakhtin's conversation of languages in the text, the oral environment of framed narratives allows the participation of the audience in the text, whether it is mutual or in the form of facial expression for approval or asking question etc. Thus framed narrative implicitly enquires the reader or audience to be mentally involved and participate in the process of storytelling.

The most classic usage of frame stories can be seen in the text of The Thousand and One Nights where the embedded stories of Scheherazade are included in the frame story of King Shahryar and his wife's betrayal. As Peter Brook suggests one of the main reason for telling and listening to stories in the Thousand and One Nights is desire.

Narration... is seen to be life-giving in that it arouses and sustains desire, ensuring that the terminus it both delays and beckons toward will offer what we might call a lucid repose, desire both come to rest and set in perspective.... Desire becomes reinvested in tellings of and listenings to stories, it is reconstituted as metonymy--over a thousand and one nights until the Sultan can resume a normal erotic state, marrying Shahrazad, who thus fulfills her name as "savior of the city."(60-61)

\section{Barth under the Spell}

John Barth's used frame tale as a narrative strategy to achieve the same effect that the oral traditional narrators seek for. Barth discovered the oriental legacy of frame tale narrative early in his academic life and is mostly influenced by seventeen volumes of Richard Burton's translation of The Thousand and One Nights:

My love affair with Scheherazade is an old and continuing one. As an illiterate undergraduate, I worked off part of my tuition filing books in the Classics Library at Johns Hopkins, which included the stacks of the Oriental Seminary. One was tacitly permitted to get lost for hours in that splendrous labyrinth and to intoxicate, engorge oneself with story. Especially I became enamored of the great tale-cycles and collections: Somadeva's Ocean of Story in ten huge volumes, Burton's Thousand Nights and a Night in seventeen, the Panchatantra, the Gesta Romanorum, the Novellini, and the Pent-Hept-and Decameron. If anything ever makes a writer out of me, it will be the digestion of that enormous, slightly surreptitious feast of narrative.(F.B. 51)

Despite his familiarity with many frame tale narratives, Barth specifically praise Scheherazade for her art of storytelling as he indicates "Most of those spellbinding liars I have forgotten, but never Scheherazade. Though the tales she tells aren't my favorites, she remains my favorite teller" $(51)$ indeed one can hardly understand John Barth's writings without recognizing his obsession with Scheherazade and the Thousand and One Nights. He mentions her name in his essays, lectures, stories, novellas and novels. It seems that Barth cannot escape the enchantment and is forever trapped in the frame tale of the Nights. Barth's admiration of Scheherazade's technique is further explained in his essay, "Tales within Tales within Tales," a lecture he prepared for the Second 
International Conference on the Fantastic in the Arts, at Florida Atlantic University in March, 1981. There he depicted his close study of the master pieces of frame tale literature by running "a thorough, if non-professional," examination of about frame tale convention through the ancient examples of framed narratives like Chaucer's Canterbury Tales, or Dante's The Divine Comedy and the majestic The 1001 Nights, "to discover something about that ancient narrative convention which might inspire a story of my own: a story which, whatever else it was about, would also be about stories within stories within stories."(160) he confessed that "it was never Scheherazade's stories that seduced and beguiled me, but their teller and the extraordinary circumstances of their telling: in other words, the character and situation of Scheherazade, and the narrative convention of the framing story".(157) Barth categorized the framed narratives into two major groups. In the first group there are those with "incidental or casual frames" and in the second one stand the "more or less systematic frames". What mostly concerned him is the second group which includes the distinguished frame tales of the Nights. These "stories that programmatically frame other stories" are sometimes embedded in one primary frame as in Dante's The Divine Comedy, Chaucer's Canterbury Tales," that comprises only "two degrees of narrative development -- tales within a tale" or in rare cases composed of "serial primary frames" as the oriental stories like the The 1001 Nights ,where "the second degree of narrative (Scheherazade's stories) becomes a serial frame within a single frame (the story of Scheherazade) [w] here the characters on the third level of narrative involvement more than once tell further stories."(161-162) In this organized analysis Barth explored the relationship between the framed and the framing stories and divided them into three major categories according to complication and relation to other narrative levels . First and the most frequent ones are those that make "little or no connection between the contents of the framed and the framing stories" like most part of The Divine Comedy or Canterbury Tales or even The 1001 Nights. (166) The formula for starting the unrelated story is like this in the Nights: "And yet, O King! this is not more wondrous than the story of..."( Burton 25) or " And you,[...] have ye no story or rare adventure to amuse us withal?".(Burton 29) The second group in which most of the literary frame tales are placed, is referred to those stories where there is an "associative, thematic, or exemplary (or cautionary or prophetic) relationship"(166) between the framed and the framing story. These stories are included in the Nights too. For Scheherazade's stories about faithfulness of the wife that resemble her own situation are among them. The final and most significant group are those with "dramaturgical relation"(167) Barth elaborates the case for the Nights with this quotation:

Aha," Shahryar might be said to say to himself here and there in the Nights: "I see now that my own cuckolding is as nothing compared to X's; moreover, the story of Y suggests that my misogyny may have been an overreaction, particularly given such a brave, wise, and beautiful storyteller. Perhaps I should consider not executing my bedpartners every morning."(qtd. in Barth 167)

Barth explained that in case of "high-level dramaturgical relation" where the characters of the frame tale are the same as the characters within the framed stories the "inside" story can reverse the climax or the action of the "outside" story.(167) It is Scheherazade's frame tale that is reiterated by him almost every essays of his The Friday Book: Essays and Other Nonfiction (1984) in one of these essays, which was supposed to be a piece about the Black Humorist-which he was once considered to be a part of; Barth wrote an open letter about Scheherazade, and apologizes for knowing nothing about Black Humor. There he invokes her as a muse and says "I beseech the Muse to keep me from ever becoming a Black Humorist."(50) he further more delineate his fondness to Scheherazade as "the aptest, sweetest, hauntingest, hopefullest I know for the storyteller" and explained his admiration with the frame story this way:

The whole frame of those thousand nights and a night speaks to my heart, directly and intimately -- and in many ways at once, personal and technical. The sultan Shahryar, you 
remember, is so disenchanted with life in general and love in particular that he "marries" a virgin every night and has her killed in the morning. Scheherazade, who has "perused the books, annals, and legends of preceding kings, and the stories, examples, and instances of bygone men. . . antique races and departed rulers," volunteers herself. The King "abates her virginity" (as if it were an intense condition), whereafter, with the prearranged assistance of her younger sister, Dunyazade -- about whose role much might be said --Scheherazade beguiles her deflowerer with a tale, artfully continued, involuted, compounded, and complicated through a thousand and one nocturnal installments, during the invention of which she also bears three sons by her imperious audience.(51)

Considering Barth's fascination with Scheherazade and her frame tale and tracing that in his works, one could begin to understand why he chose to employ this traditional technique in his own narratives. Barth has been labeled variously as a novelist of late fifties and early sixties. He was considered as existentialist by Ihab Hassan, and absurdist by Charles B. Harris, a black humorist by MaxF. Schulz, and a fabulist by Alan Trachtenberg and Robert Scholes.(Clavier 1) However they may have forgotten to realize the role of Scheherazade in Barth's writings which is very well expressed in his The Friday Book. The essays obviously reveal Barth's infatuation of Scheherazade and his indebtedness to Burton's translation of The Thousand and One Nights. Barth admires other frame tales like Chaucer's The Canterbury Tales and states that "Chaucer's frame, for example, the pilgrimage to Canterbury is an excellent if venerable ground-metaphor -- life as a redemptive journey -- but, having established it, he does nothing with it."(52) Or he considers the frame tale in Boccaccio's Decameron where the wealthy ladies and gentlemen amuse themselves with stories while the plague of 1348 ravaged the countryside "more arresting for its apocalyptic nature, for the pretty rules with which the company replaces those of their literally dying society[...] and for the occasional relevance of the tales to the tellers and to the general situation."(52) However he believed that the story of Scheherazade "excels" all since it is "more magical and dreamish".(52) Her condition, Barth suggested is perhaps more apocalyptic than the Decameron's because the king's despair would ruin the whole kingdom and it is Scheherazade who must impress her in a "publish-or-perish" situation.

Barth's appreciation of Scheherazade is a sincere intellectual interest in the archetypal storyteller and should not be dismissed as a peculiar obsession. He finds his own life as a storyteller in the same "publish or perish" situation similar to Scheherazade's thus he maintains to delineate her narrative strategy in his own fictions. He objected those who like Joyce's Dedalus, call "history a nightmare from which he's trying to wake" or found it more as a "wet-dream", since he believes the past is a dream in which he laughs.(52) For Barth using "historical or legendary material, especially in a farcical, even a comic, spirit, has a number of virtues, among which are esthetic distance and the opportunity for counterrealism."(52) Barth's writing remind us over and over, a fictional writer's suffering from the writer's block and they symbolically reiterate Scheherazade's apocalyptic situation. He regards her as an emblem of his "figurative aspiration":

When I think of my condition and my hope, musewise, in the time between now and when I shall run out of ink or otherwise expire, it is Scheherazade who comes to mind, for many reasons -- not least of which is a technical interest in the ancient device of the framing-story, used more beautifully in the Nights than anywhere else I know.(51-52)

Barth considers Scheherazade's story as a metaphor for the condition of the storytellers or "narrative artists" in general. The artist is always threatened by the audience's lack of interest or criticism. Similarly Scheherazade's audience, the king, is an "absolute critic" who listen to the stories with "publish or perish policy moreover her talent is "always on the line" no matter how many times she had pleased the king. (104) Barth praises the convoluted style of Scheherazade's stories and the way she shape her narrative in that apocalyptic situation. As "a professional storyteller" and "an amateur 
of frame-tale literature" he contemplates in Scheherazade's complex tales within tales and concludes:

Scheherazade tells by my count 169 primary tales; she moves to the second degree of narrative involvement on no fewer than nineteen occasions, to tell 87 tales within the primary tales, and to the third degree on four occasions, to tell eleven tales-within-taleswithin-tales -- 267 complete stories in all, which by the way include about 10,000 lines of verse, by Burton's estimate.(191)

Barth is mesmerized by Scheherazade's intricate weaving of frame stories and her passionate virtuosity in storytelling. As she enters the King's chamber, she knows too well that her performance in storytelling is critical for her own life and the lives of the virgins in her country. Therefore she lays a narrative trap for the king to guarantee the outcome. She design her first story to be told in half and to be continued. In this respect her first story includes three sub tales which are enframed by the first story and are narrated by the characters in it. Theses narratives are stopped as Scheherazade falls silent by the dawn "leaving not one but two plots suspended as a kind of narrative insurance."(189) Then her sister Dunyazade praises the half-told story as she was instructed to do, yet like a modest story teller Scheherazade shrugs and says "What is this [compared] to what I could tell thee on the coming night, were I to live and the King would spare me?"" which is a hopeful self-deprecation to which the King would answer ""By Allah, I will not slay her, until I shall have heard the rest of her story."'(qtd. in F.B. 189) Thus the enchanted Shahryar postpone the execution to the following night, not knowing that Scheherazade's frame tale stories could lead to a thousand and one nights. Framing is a strategy is the source of her passionate virtuosity which is a quality that as Barth regard is very important for a storyteller or writer. What Scheherazade possess is both the "fire" and "algebra"; two characteristics that Barth considers are vital for good literature since "algebra" stands for "technical and formal aspects of a work of literature" and "fire" for the "passion".(123) Barth barrowed the terms from Jorge Luis Borges who is not less fascinated with the frame tales or simply stories within stories. Borges indicates that the structure appeal to us because "they disturb us metaphysically" and remind us of the external frame or as Barth declares,

"the fiction of our own lives, of which we are both the authors and the protagonists, and in which our reading of The 1001 Nights, say, is a story within our story. This speculation of Borges's strikes me as wise and unexceptionable.”.(168)

Despite Barth's adherence to Borgesian thinking, He particularly observes Tzvetan Todorov's comprehensive analysis of frame tale and embedded narratives with great interest. In his essay "Tales within Tales within Tales." Barth mentioned that this famous Bulgarian/French philosopher and literary critic introduced "embedded stories" in his The Poetics of Prose. As a formalist/structuralist Todorov draw a parallel between these stories and a specific syntactic form of sentence linguistically called embedding( Italic is in the original FB 168) Barth translated Todorov's example for the embedding in a sentence:

Whoever the man who the post which on the bridge which on the road which to Worms goes, lies, stood, knocked over, identifies, gets a reward.(169)

Todorov explains this in his essay "Narrative-men," in The Poetics of Prose,

... the appearance of a noun immediately provokes a subordinate clause which, so to speak, tells its story; but since this second clause also contains a noun, it requires in its turn a subordinate clause, and so on, until an arbitrary interruption, at which point each of the interrupted clauses is completed one after the other. The narrative of embedding has 
precisely the same structure, the role of the noun being played by the character: Each new character involves a new story.(Todorov qtd. in Barth 169)

Fascinated by this analogy, Barth added to Todorov's remark that "If the nouns are characters [...] the subordinate clauses are tales within the frame tale of the main clause".(169) Furthermore Todorov suggested that narrating stories is literally equal to living.(169) Referring to the stories of the 1001 Nights, Todotov also suggested that Scheherazde's story is a reminder for what will happen if one stops telling stories, it is the inevitable death since figuratively each one of us " tell stories and listen to them because we live stories and live in them".(Barth 169)

Though Barth is indebted to Borges and Todorov for their philosophical and structural notions about the nature of the frame stories or tales within tales, he explains his own view on the global popularity of this structure in plain words:

[F]rame tales fascinate us perhaps because their narrative structure reflects, simply or complexly, at least two formal properties not only of syntax but of much ordinary experience and activity: namely, regression (or digression) and return, and theme and variation.(169170)

\section{CONCLUSION}

The American Postmodernist, John Barth, who is recalled as an existentialist, absurdist or Black Humorist by many critics, does not subscribe to any literary theory as Harris suggested (12) and tend to create his own unique theoretical and technical strategies in his writings. His novels depict his inclination toward traditional storytelling techniques, like framing and embedding. Barth's fascination to the ancient frame tale of the Thousand and One Nights is predominant both in his fictional and non-fictional writings. He pays his homage to Scheherazade, the narrator of the Thousand and one Nights, by invoking her numerously as his muse in his essays and employing her narrative strategy in his postmodern fictions like Chimera. By investigating Barth's essays one can find a resolution for Barth's frantic exploitation of the framing device and understand his unique application of reenactment that replenish the exhausted materials in novel writing.

\section{References}

[1] Al-Madani, Yusur. "Deconstructing and Reconstructing a Narrative of the Self: John Barth's the Last Voyage of Somebody the Sailor." International Fiction Review 26.1 (1999). Print.

[2] Al-Olaqi, Fahd Mohammed Taleb Saeed. "The Influence of the Arabian Nights on English Literature: A Selective Study." European Journal of Social Sciences 31.3 (2012): 384-96. Print.

[3] Bakhtin, Mikhail M. "The Dialogic Imagination: Four Essays by Mm Bakhtin (M. Holquist, Ed.; C. Emerson \& M. Holquist, Trans.)." Austin: University of Texas Press, 1981. Print.

[4] Bal, Mieke. Narratology: Introduction to the Theory of Narrative. University of Toronto Press, 2009. Print.

[5] Barth, John. Chimera. Houghton Mifflin Harcourt, 1972. Print.

[6] ---. The Friday Book: Essays and Other Nonfiction. Johns Hopkins University Press, 1997. Print.

[7] ---. Lost in the Funhouse. Anchor, 2014. Print.

[8] Barth, John, and Arte Johnson. The Last Voyage of Somebody the Sailor. Little, Brown, 1991. Print. 
[9] Bressler, Charles E. "Literary Criticism." An Introduction to theory and practice (2007). Print.

[10] Brooks, Peter. Reading for the Plot: Design and Intention in Narrative. Harvard University Press, 1992. Print.

[11] Burton, Richard Francis. A Plain and Literal Translation of the Arabian Nights' Entertainments, Now Entituled the Book of the Thousand Nights and a Night: With Introduction, Explanatory Notes on the Manners and Customs of Moslem Men and a Terminal Essay Upon the History of the Nights. Vol. 17: Printed by the Burton Club, 1950. Print.

[12] Connor, Steven. The Cambridge Companion to Postmodernism. Cambridge University Press, 2004. Print.

[13] Davis, Cynthia. "The Key to the Treasure": Narrative Movements and Effects in" Chimera." The Journal of Narrative Technique (1975): 105-15. Print.

[14] Faris, Wendy B. Scheherazade's Children: Magical Realism and Postmodern Fiction. na, 1995. Print.

[15] Fishburn, Evelyn. "Traces of the Thousand and One Nights in Borges." Middle Eastern Literatures 7.2 (2004): 213-22. Print.

[16] Flower, Dean. "Not Waving but Drowning." The Hudson Review (1991): 317-25. Print.

[17] Fludernik, Monika. Towards A'natural'narratology. Routledge, 2002. Print.

[18] Fogel, Stanley, and Gordon Slethaug. Understanding John Barth. Columbia: University of South Carolina Press, 1990. Print.

[19] Genette, Gérard, and Jane E Lewin. Narrative Discourse: An Essay in Method. Cornell University Press, 1983. Print.

[20] Gerhardt, Mia Irene. The Art of Story-Telling. 1963. Print.

[21] Grote, Jason. One Thousand One. Samuel French, Inc., 2009. Print.

[22] Harris, Charles B. Passionate Virtuosity: The Fiction of John Barth. University of Illinois Press, 1983. Print.

[23] Hassan, Ihab. "Toward a Concept of Postmodernism." Postmodernism: A reader 152 (1993). Print.

[24] Herman, David. "Genette Meets Vygotsky: Narrative Embedding and Distributed Intelligence." Language and Literature 15.4 (2006): 357-80. Print.

[25] ---. "Genette Meets Vygotsky: Narrative Embedding and Distributed Intelligence." Language and Literature 15.4 (2006): 357-80. Print.

[26] Hutcheon, Linda. A Poetics of Postmodernism: History, Theory, Fiction. Routledge, 2003. Print.

[27] Irwin, Bonnie. "What's in a Frame? The Medieval Textualization of Traditional Storytelling." Oral Tradition 10 (1995): 27-53. Print.

[28] Irwin, Robert. The Arabian Nights: A Companion. Tauris Parke Paperbacks, 2003. Print.

[29] Jameson, Fredric. Postmodernism, or, the Cultural Logic of Late Capitalism. Duke University Press, 1991. Print.

[30] Khan, Jalal Uddin. "The Arabian Night: A Modern Introduction." The EFL Journal 4.2 (2013). Print. 
[31] Lewis, Barry. "Postmodernism and Literature." The routledge companion to postmodernism (2001): 121-33. Print.

[32] Mackenzie, Ursula. "John Barth's Chimera and the Strictures of Reality." Journal of American Studies 10.01 (1976): 91-101. Print.

[33] Malpas, Simon, and Paul Wake. The Routledge Companion to Critical Theory. Routledge London, 2006. Print.

[34] Marzolph, Ulrich. "Narrative Strategies in Popular Literature: Ideology and Ethics in Tales from the Arabian Nights and Other Collections." Middle Eastern Literatures 7.2 (2004): 17182. Print.

[35] McHale, Brian. Postmodernist Fiction. Routledge, 2003. Print.

[36] Mernissi, Fatema. Scheherazade Goes West: Different Cultures, Different Harems. Simon and Schuster, 2001. Print.

[37] Natoli, Joseph, and Linda Hutcheon. A Postmodern Reader. SUNY Press, 1993. Print.

[38] Ouyang, Wen-Chin. "Metamorphoses of Scheherazade in Literature and Film." Bulletin of the School of Oriental and African Studies 66.03 (2003): 402-18. Print.

[39] Pier, John. "Narrative Levels (Revised Version; Uploaded 23 April 2014)." Print.

[40] Poe, Edgar Allan. The Thousand-and-Second Tale of Scheherazade. BompaCrazy. com, 1850. Print.

[41] Prince, Gerald. A Dictionary of Narratology. U of Nebraska Press, 2003. Print.

[42] Sallis, Eva. Sheherazade through the Looking Glass: The Metamorphosis of The'thousand and One Nights'. Routledge, 2013. Print.

[43] ---. Sheherazade through the Looking Glass: The Metamorphosis of The'thousand and One Nights'. Routledge, 2013. Print.

[44] Schulz, Max F. The Muses of John Barth: Tradition and Metafiction from Lost in the Funhouse to the Tidewater Tales. Johns Hopkins Univ Pr, 1990. Print.

[45] Scott, Steven D. The Gamefulness of American Postmodernism: John Barth \& Louise Erdrich. Vol. 10: Peter Lang Pub Incorporated, 2000. Print.

[46] Sim, Stuart. The Routledge Companion to Postmodernism. Routledge, 2001. Print.

[47] Todorov, Tzvetan. "The Poetics of Prose." Paris: Ithaca (1977). Print.

[48] ---. "The Poetics of Prose, Trans." Richard Howard (Ithaca: Cornell UP, 1977) 70 (1977). Print.

[49] Waugh, Patricia. Metafiction. Routledge, 2013. Print.

[50] Webster, Mark. Ancient Tale of Sinbad Frame Latest Barth Novel. Cambridge Masssachusetts: The Tech, March 12 Print.

[51] Ziegler, Heide. John Barth (Routledge Revivals). Routledge, 2014. Print.

[52] ---. "The Tale of the Author or, Scheherazade's Betrayal." (1990). Print. 